ZOOLOGIA 30 (6): 675-691, December, 2013

http://dx.doi.org/10.1590/S1984-46702013005000008

\title{
Re-characterization of the Red-lip Megalobulimus (Gastropoda: Strophocheilidae) from Peru with description of a new species
}

\author{
Victor Borda ${ }^{1,2} \&$ Rina Ramírez ${ }^{1}$ \\ ${ }^{1}$ Laboratorio de Sistemática Molecular y Filogeografía, Facultad de Ciencias Biológicas, Universidad Nacional Mayor de San \\ Marcos and Museo de Historia Natural. Av. Arenales 1256, Lima-14, Peru. \\ ${ }^{2}$ Corresponding author. E-mail: vicbp1@gmail.com
}

\begin{abstract}
Megalobulimus K. Miller, 1878 is a genus of land snails that includes the largest living snails in the Neotropics. The main goal of this paper was to review all species of Megalobulimus that have a red lip, and which are distributed in Peru. We carried out a detailed description of their shells and soft parts, and conducted a multivariate analysis on their shells and geographic distribution. There are two species reported from Peru, Megalobulimus capillaceus (Pfeiffer, 1855) and Megalobulimus separabilis (Fulton, 1903). Megalobulimus capillaceus is known to occur in three regions - San Martín, Huánuco and Cusco - but the Cusco population is undoubtedly different from all remaining populations, and is recognized herein as a new species, Megalobulimus florezi sp. nov. This species has a more elongated shell, penis clubshaped, epiphallus longer, and free oviduct longer than M. capillaceus. By contrast, the male genitalia of M. separabilis is filiform and does not present an external diverticulum in the free oviduct.
\end{abstract}

KEY WORDS. Anatomy; genitalia; land snails; pallial complex; shell.

The Neotropics are among the most biodiverse regions in the world (RuLL 2007) and the regions' ecological and economic relevance is indisputable (Tundisi \& Matsumura-Tundisi 2008). Many Neotropical species have been used as models to answer questions about ecology, evolution and biogeography, but at the same time most of these species remain poorly characterized. Peruvian people have used mollusks since pre-Hispanic times, mainly for food (Engel 1970, Ravines 1991). Today, the tradition of eating snails is restricted to the people in the Amazon region, who prefer species of Megalobulimus K. Miller, 1878 (RAmírez \& Cáceres 1991). This genus includes the largest land snails in the Neotropics. A total of 81 species have been described in it, 61 of which occur in Brazil (SimONe 2006, 2012) and nine in Peru (RAmírez et al. 2003). The species in Megalobulimus, like other mollusks, have been described based on conchological characters (BEQUaERT 1948, Leme 1964, Bieler 1992), including shape and size of the shell and color of the peristome.

Similarities in conchological characters have led to misidentifications, however. For example, Megalobulimus capillaceus (Pfeiffer, 1885) has been confounded with Megalobulimus separabilis (Fulton, 1903), and even with juvenile specimens of Megalobulimus musculus (Bequaert, 1948), because all of them have a red lip (BEqUaERT 1948). For these reasons, and also the fact that the original descriptions are based on shell characters, the species of Megalobulimus have not been adequately differentiated. LEME (1973) established a diagnosis for Megalobuliminae on the basis of anatomical characters such as presence of a buccal fringe, kidney without any vestige of primary ureter, roof of pulmonary chamber with longitudinal septum, and intestine with pre-rectal valve. He considered Megalobulimus to be a primitive group and commented that most anatomical characters are constant and homogeneous, making it difficult to differentiate among species.

In the present review we recognize three red-lipped species of Megalobulimus from Peru: M. capillaceus, also known from Brazil, Bolivia and Paraguay; M. separabilis only known from Peru; and Megalobulimus florezi sp. nov., herein described from Cusco (Peru).

\section{MATERIAL AND METHODS}

Specimens were collected in 2008, 2009, and 2012 from different localities in the San Martín, Huánuco and Cusco regions. The collecting method was qualitative visual searching (Coppolino 2010) in forests and backyards. We also used shells of $M$. capillaceus, M. separabilis, and M. musculus from the malacological collection of the Museo de Historia Natural of Universidad Nacional Mayor de San Marcos, Lima (UNMSM). Descriptions of the shell and other anatomic features were based on the topotypes of each species. The terminology used for shells was based on Burch (1962). Anatomical dissections were performed according to Leme (1973). The terminology for anatomical descriptions was based on Leme (1973), BonfatTI (1980), Simone \& Leme (1998), Gómez (2001), and Dimitriadis (2001). In order to evaluate shell similarities at intra and inter population levels, we analyzed shell measurements of 80 adult $M$. capillaceus ( 58 from San Martín and 22 from Huánuco), 18 shells of M. florezi sp. nov. (Cusco) and 40 of M. separabilis. Eight 
variables (Fig. 1) were considered: 1) shell height (SH);2) shell width (SW); 3) spire height (SpH); 4) position of major diameter (PMD); 5) lateral width (LD); 6) aperture height (AH); 7) aperture width (AW); and 8) number of whorls (NW). We only considered adults those specimens that possessed a wide and red peristome. The measurements were subjected to Principal Component Analysis (PCA) in SPSSv20 software (NIE et al. 2011). Distribution information was recovered from field trips, malacological collections from the Museo de Historia Natural of the UNMSM and information from electronic databases from collections of the following museums: Field Museum of Natural History (FMNH) of Chicago; Florida Museum of Natural History (FLMNH); Museum of Comparative Zoology of Harvard University (MCZ) of Massachusetts; Academy of Natural Sciences of Philadelphia (ANSP); Natural History Museum of London (NHMUK); and from the global database of the Global Biodiversity Information Facility (GBIF). In addition, we received photographs of shells of types and other specimens of Bulimus capillaceus (Pfeiffer, 1855), Strophocheilus separabilis Fulton, 1903, from the Natural History Museum of the United Kingdom and Borus capillaceus (Pfeiffer, 1855) from the National Museum of Natural History.

Acronyms for Museums: Field Museum of Natural History, Chicago (FMNH); Museum of Natural History, Florida (FLMNH); Museo de Historia Natural de la UNMSM, Lima (MUSM); Museu de Zoologia da Universidade de São Paulo, São Paulo (MZUSP); Natural History Museum of the United Kingdom (NHMUK); Senckenberg Forschungsinstitut und Naturmuseum, Frankfurt (SMF); Universidad Nacional San Antonio de Abad del Cusco, Cusco (UNSAAC); Universidad Nacional Mayor de San Marcos, Lima (UNMSM); National Museum of Natural History (USNM).

Abbreviations: Albumin gland (ag), annex glandular sac (an), anterior esophagus (as), collector channel (cc), crop (cr), duct of anterior digestive gland (da), duct of the spermatolitic bursa (db), deferens duct (dd), diverticulum of free oviduct (do) duct of posterior digestive gland (dp), epiphallus fold (ef), epiphallus granulations (eg), epiphallus (ep), esophagus (es), esophagic typhlosole (et), first segment of intestine (fi), flagellum (fl), free oviduct (fo), genital atrium (ga), glandular body (gb), gland capsule (gc), gastric shield (gs), hermaphroditic duct (hd), heart (ht), internal diverticulum (id), internal folded surface of spermioviduct (if), irregular granulations (ig), internal smooth surface of spermioviduct (is), intestinal typhlosole (it), kidney (kd), longitudinal groove (lg), middle esophagus (me), nephrostome (np), opening of the duct of the spermatolitic bursa (od), oviduct folds (of), ovotestis (ot), penis (pe), penial folds (pf), prostatic gland (pg), posterior esophagus (ps), prerectal valve $(\mathrm{pv})$, pulmonary septum $(\mathrm{pu})$, ridges $(\mathrm{rd})$, retractor muscle (rm), rectum (rt), salivary glands (sg), small lifting (sl), small transversal folds (tf), spermatolitic bursa (sb), spermioviduct (sp), stomach (st), talon (ta), ureteric groove (ug), vaginal folds (vf), vagina (vg), v-ridges (vr), vessels (vs).

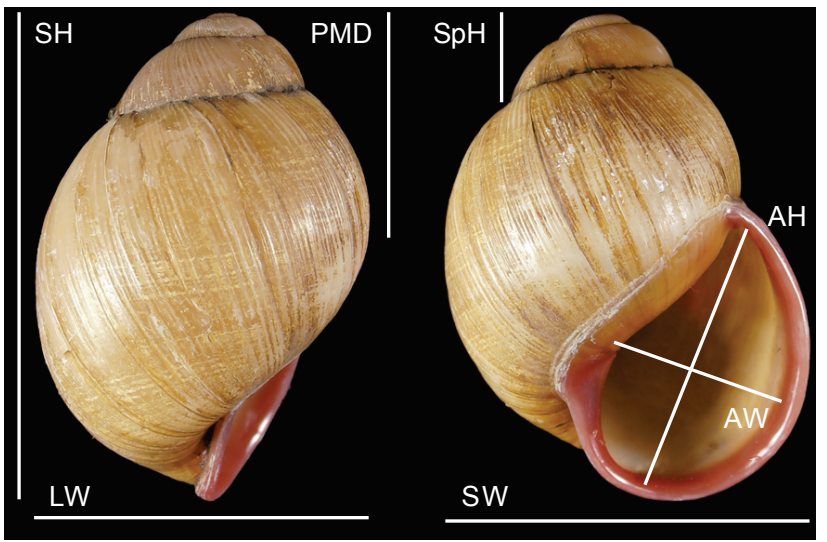

Figure 1. The following shell variables were evaluated: shell height $(\mathrm{SH})$, shell width $(\mathrm{SW})$, spire height $(\mathrm{SpH})$, position of major diameter (PMD), lateral width (LD), aperture height $(A H)$, and aperture width (AW).

\section{TAXONOMY}

\section{Megalobulimus capillaceus (Pfeiffer, 1855)}

Figs 2-4, 11-20

Bulimus capillaceus Pfeiffer, 1855: 93.

Bulimus (Borus) capillaceus: Pfeiffer, 1856: 147.

Bulimus rosaceus: Morelet, 1863: 170.

Bulimus (Borus) oblongus var. capillaceus: v. Martens, 1876: 19. Bulimus oblongus var. capillacea: E.A. Smith, 1894: 137.

Strophocheilus (Borus) capillaceus: Pilsbry, 1895: 69.

Strophocheilus (Megalobulimus) capillaceus: Bequaert, 1948: 120. Megalobulimus capillaceus: Ramírez \& Cáceres, 1991: 67; Ramírez et al. 2003: 52; Simone, 2006: 208.

Types. Lectotype and two paralectypes NHMUK 1855 20130002.

Type locality. "Banks of river Solimoes" (Pfeiffer, 1855) Upper Amazonas, probably in Northeastern Peru (BEQUAERT 1948).

Diagnosis. Shell medium-sized, conic, with riblets; penis cylindrical, internal penial folds anastomosed at proximal third. Vagina longer than free oviduct; kidney similar to pulmonary septum in length (6/7).

Description. Living animals: Color: orange-brown; head and foot equal in color. Two lobulated buccal palps. Gonopore posterior to right omatophore. Shell (Figs 2-4, Table I): conic, small (up to $66 \mathrm{~mm}$ tall). Wider region above middle shell height. First and second whorls flattened. Third and fourth whorls with thinner riblets, from suture to suture. Small granulations with spiral disposition between each riblet, appearing from second whorl and reaching corporal whorl. Spire about $1 / 7$ height of shell. Sutures deep. Periostracum between orange and brown. Aperture elliptic, red peristome. Umbilicus covered by outer lip. Digestive system (Figs 13-15): Buccal mass elliptic, highly muscular, with posterior region slightly later- 


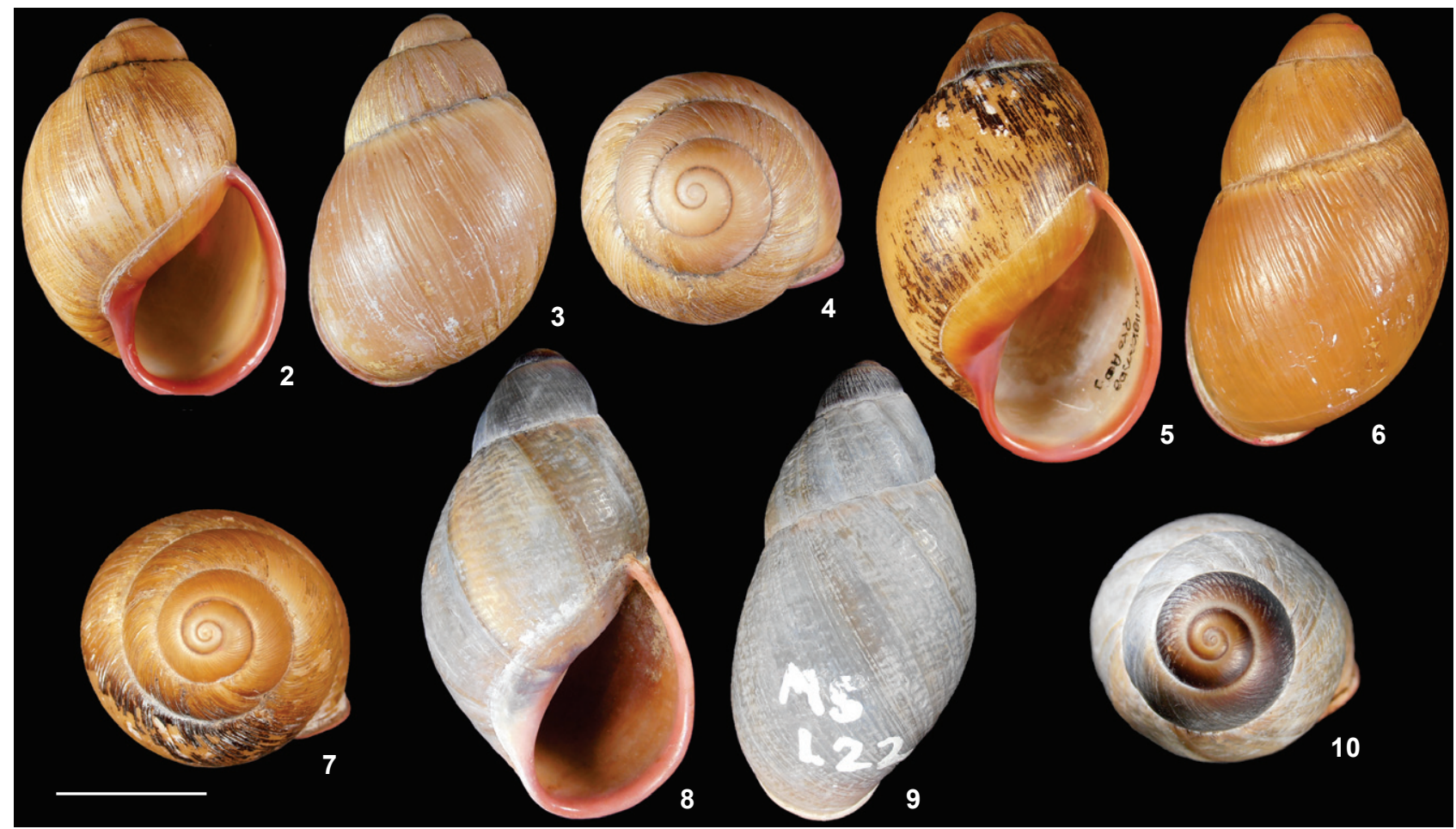

Figures 2-10. Shells of red lip Megalobulimus in apertural, rear, apical and umbilical views. (2-4) M. capillaceus (MUSM5585); (5-7) M. florezi sp. nov., holotype (MUSM 5005); (8-10) M. separabilis (MUSM5596). Scale bar: 20 mm.

Table I. Measurements of specimens of Megalobulimus capillaceus, M. florezi, and M. separabilis.

\begin{tabular}{|c|c|c|c|c|c|c|c|c|c|}
\hline \multirow{2}{*}{ Variables } & \multicolumn{3}{|c|}{ M. capillaceus $(\mathrm{n}=80)$} & \multicolumn{3}{|c|}{ M. florezi sp. nov. $(\mathrm{n}=18)$} & \multicolumn{3}{|c|}{ M. separabilis $(n=40)$} \\
\hline & Minimum & Maximum & $\begin{array}{c}\text { Mean } \pm \\
\text { Std.deviation }\end{array}$ & Minimum & Maximum & $\begin{array}{c}\text { Mean } \pm \\
\text { Std.deviation }\end{array}$ & Minimum & Maximum & $\begin{array}{c}\text { Mean } \pm \\
\text { Std.deviation }\end{array}$ \\
\hline Height & 55.00 & 67.00 & $61.12 \pm 2.75$ & 61.00 & 70.00 & $65.65 \pm 2.42$ & 57.00 & 68.00 & $62.32 \pm 2.61$ \\
\hline Width & 37.30 & 47.90 & $42.07 \pm 1.89$ & 40.00 & 44.50 & $42.41 \pm 1.19$ & 32.20 & 39.20 & $36.06 \pm 1.60$ \\
\hline Aperture height & 28.97 & 37.86 & $33.84 \pm 1.85$ & 29.78 & 36.14 & $33.96 \pm 1.71$ & 26.88 & 32.82 & $30.34 \pm 1.41$ \\
\hline Aperture width & 17.07 & 22.70 & $19.81 \pm 1.09$ & 17.87 & 20.81 & $19.04 \pm 0.83$ & 16.32 & 19.92 & $18.12 \pm 0.85$ \\
\hline Spire height & 7.35 & 12.91 & $9.52 \pm 1.11$ & 10.48 & 15.67 & $12.86 \pm 1.27$ & 12.04 & 17.86 & $14.77 \pm 1.37$ \\
\hline Position of major diameter & 23.38 & 31.86 & $27.21 \pm 1.66$ & 28.87 & 35.00 & $31.64 \pm 1.75$ & 27.62 & 35.96 & $32.69 \pm 1.83$ \\
\hline Lateral width & 34.88 & 41.71 & $38.19 \pm 1.45$ & 35.64 & 39.60 & $37.29 \pm 0.97$ & 28.12 & 32.28 & $30.38 \pm 1.03$ \\
\hline Number of whorls & 5.00 & 5.50 & $5.25 \pm 0.12$ & 5.30 & 5.90 & $5.53 \pm 0.15$ & 5.00 & 5.40 & $5.23 \pm 0.12$ \\
\hline
\end{tabular}

ally expanded, radular pouch ventral. Retractor muscle inserted ventrally to buccal mass, anteriorly to radular pouch. Esophagus emerging dorsodistally to buccal mass, with three segments of equal size: anterior, middle and posterior. Anterior segment with taller ridges. Salivary glands attached to anterior segment of esophagus. Ducts of salivary glands open in buccal mass. Middle segment (crop) expanded with thicker ridges, except in middle zone, which is smooth. Posterior segment with many thin ridges and expansion seeming slightly cropped. Posterior segment receiving duct of anterior digestive gland. Esophagic typhlosole arising from duct of anterior digestive gland, reaching middle of stomach, increasing in thickness, with blunt end. Thin ridge arising from same duct, running parallel to esophagic typhlosole. Both end up in middle region (gastric shield) of stomach. Stomach reniform, muscular. Posterior digestive gland connected to stomach through duct terminating 


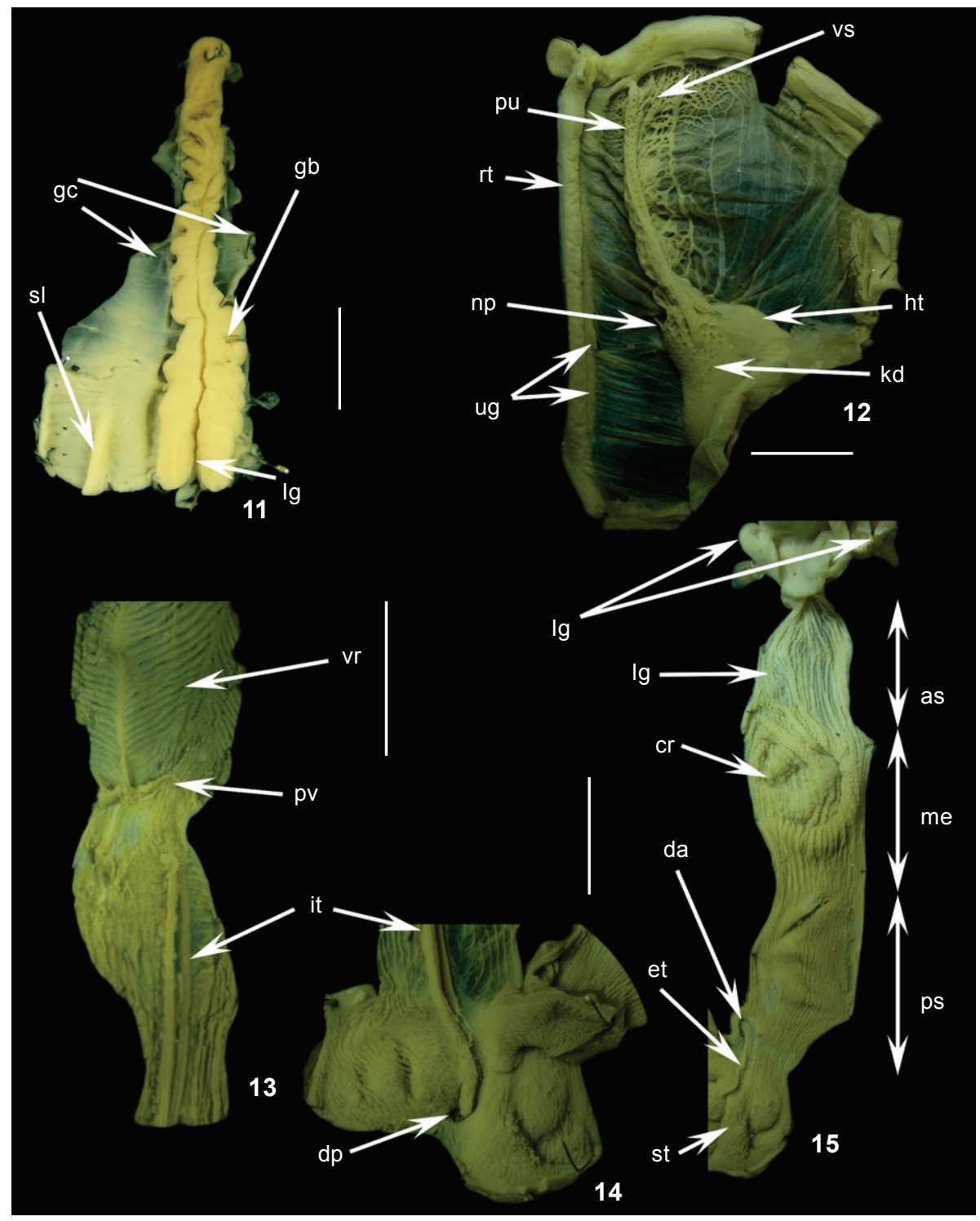

Figures 11-15. Soft parts of $M$. capillaceus: (11) internal view of the pedal gland; (12) pallial complex; (13) internal surface of intestine; (14) internal surface of stomach; (15) internal surface of esophagus. Scale bars: $11=5 \mathrm{~mm}, 12-15=10 \mathrm{~mm}$.

next to gastric shield. Stomach with central, thin and smooth surface where esophagic and intestinal typhlosoles converge. Thicker walls near esophagus and intestine. Internal surface near intestine with wavy ridges. Intestine threefold esophagus length, with three segments, first segment extending from stomach to pre-rectal valve. Externally, pre-rectal valve like two bulges with lobed edges. Intestinal typhlosole with folded surface, blunt end, arising from duct of posterior digestive gland, terminating close to pre-rectal valve. Lower ridges present, two thicker; one running near typhlosole and ending near end of typhlosole; other reaching pre-rectal valve. Middle segment of intestine extends from pre-rectal valve, with oblique ridges that converge in a longitudinal ridge taking V-disposition. Distal region of intestine (rectum) is the longer one, has ridges with $\mathrm{V}$-disposition, opens in anus beside pneumostome in mantle edge. Pallial complex (Fig. 12): Septum divides cavity into two regions, excretory (right side) and pulmonary (left side); covered by network of vessels (rete mirabile-like) that expands to both sides of septum and partially covers kidney and pericardium (heart). Major expansion of network in pulmonary region, with two principal and longitudinal vessels. Vessel nearest to septum with major caliber and more ramified than other longitudinal vessels. Second nearest result of confluence of smaller vessels that join at the same level of anterior third or 
middle of septum. Triangular kidney, similar length to septum (6/7). Ureters absent. Nephrostome on anterior third of right side of kidney. Posterior end of kidney does not reach posterior end of ureteric groove, which is flanked by septum and rectum. Heart covered by pericardium, sited anterior to kidney, which is half its length. Reproductive system (Figs 1620): Ovotestis attached to posterior digestive gland; with three to five conducts ending on hermaphroditic duct. Central portion of hermaphroditic duct dilated, stowed. Distal portion ending at talon. Talon attached to annex glandular sac, with thick wall; two chambers internally, one connected to hermaphroditic duct; chambers converging to common duct into which albumin gland and annex glandular sac deposit their secretions. Annex glandular sac piriform, attached to concave region of albumin gland; inner surface rough with small concavities. Albumin gland reniform, variable in size, creamy color. Spermoviduct cylindrical, muscular, slightly curved. Prostatic gland extending over dorsal surface of spermoviduct, pink in color with transversal folds. Ventral surface of spermoviduct slightly translucent. Internally, with two parallel regions; one with surface with protrusions arranged like irregular plates, other with small transversal folds. Both regions have creamy color. Internally, prostatic gland with many small ducts that end independently on collector channel that runs along the gland and continues with deferens duct, which is hidden at the beginning, then appears externally on free oviduct. Free oviduct muscular with external bulb-like diverticulum located in middle of its length and opposite to spermatolitic bursa duct. Inner surface of oviduct with many wide folds, some of which reach diverticulum. Vagina longer than free oviduct. Outer surface of vagina similar to free oviduct. On inner surface, proximal region with thicker folds than those of free oviduct, but thickness of these folds decreases as they arrive at genital atrium. Spermatolitic bursa piriform, variable in size. Deferens duct thin, ending suddenly on epiphallus, which lies on penis. Epiphallus with two short flagella of similar or different lengths. Inner surface of epiphallus with small granulations; with thick fold (pilaster) that originates at its proximal end and then divides in two at end of first fifth of epiphallus length. Two new folds have homogenous surfaces, their thickness decreases as they approach distal end. In some cases, these folds converge in a single fold close to distal end. Another fold that begins from the middle of epiphallus, terminates at penis. This fold wider but low, almost at the same level of the epiphallus inner surface. Penis muscular, cylindrical, threefold epiphallus length. Retractor muscle with unique insertion at variable position on penis, apical or subapical. Its length is one third of penis length. Internally, penial folds anastomosed to finish at proximal third; these folds have network aspect, their thickness decreases to a low relief. Genital atrium almost indistinguishable. Pedal gland (after Borda et al. 2010; Fig. 11): Triangular, borders undulated, depressed, length $(23.45 \mathrm{~mm})$ spans visceral cavity in contracted specimen. Anterior third

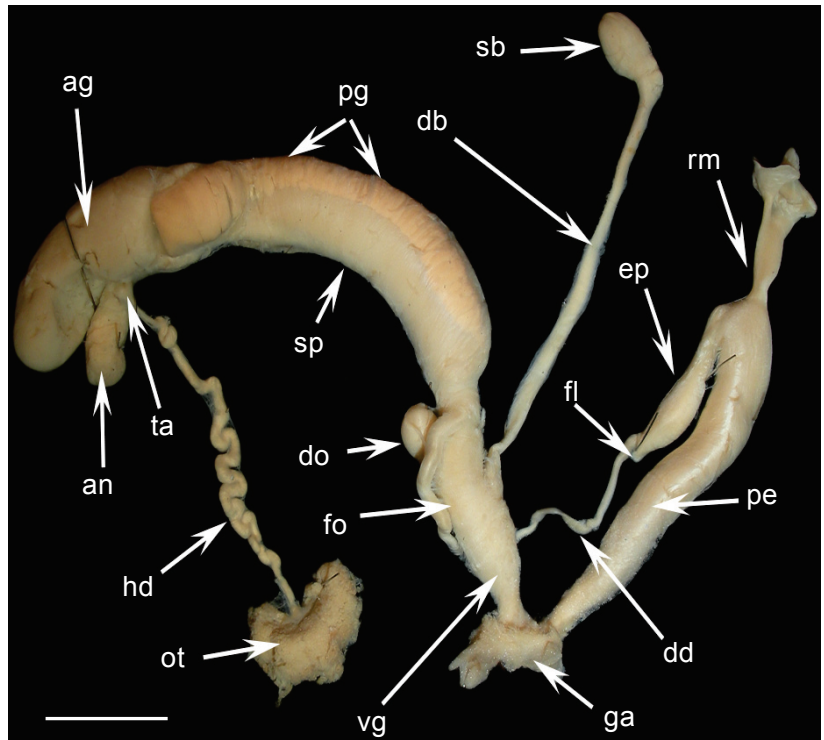

Figure16. Genital system of M. capillaceus from San Martín region. Scale bar: $10 \mathrm{~mm}$.

with width constant. Dorsal side of anterior third covered by thin connective tissue, then free to posterior end; posterior third thin, blunt, attached to foot by few connective bundles arising from lateral borders. Gland capsule semi-transparent. Lumen reduced, spanning entire gland length. Glandular body prominent with cream color, smooth surface; it dangles from capsule roof by projections retained to dorsal surface; medium longitudinal groove spans its entire length. Groove depth shallower in posterior region. Inside the glandular body, glandular acinous separated from each other by capsule roof projections. Capsule floor smooth with small lifting along middle line of anterior portion coinciding with gland body groove.

Distribution (Fig. 21): Distributed in the San Martín and Huánuco regions, Peru. In San Martín, it is present throughout almost the entire region, whereas in Huánuco, it is distributed only in the northern part of the region, which is humid. It is important to note that SMITH (1894) reported this species for Yurimaguas in the Loreto region. Yurimaguas is only a few kilometers from the San Martín region; for this reason it is likely that the distribution of M. capillaceus may reach Loreto.

Habitat. Megalobulimus capillaceus inhabits dry forest and premontane humid forests, being also common in gardens and backyards next to the forest. Individuals of this species are very conspicuous during the rainy season, whereas in the dry season they remain buried.

Remarks. The thickness of the peristome differs between the material examined and the types of M. capillaceus from the NHMUK (NHMUK 1855 - 20130002) (Fig. 22). This feature is variable and depends on the age of the individuals. Otherwise, the proportions, shape, and sculpture of the shell are the same. 


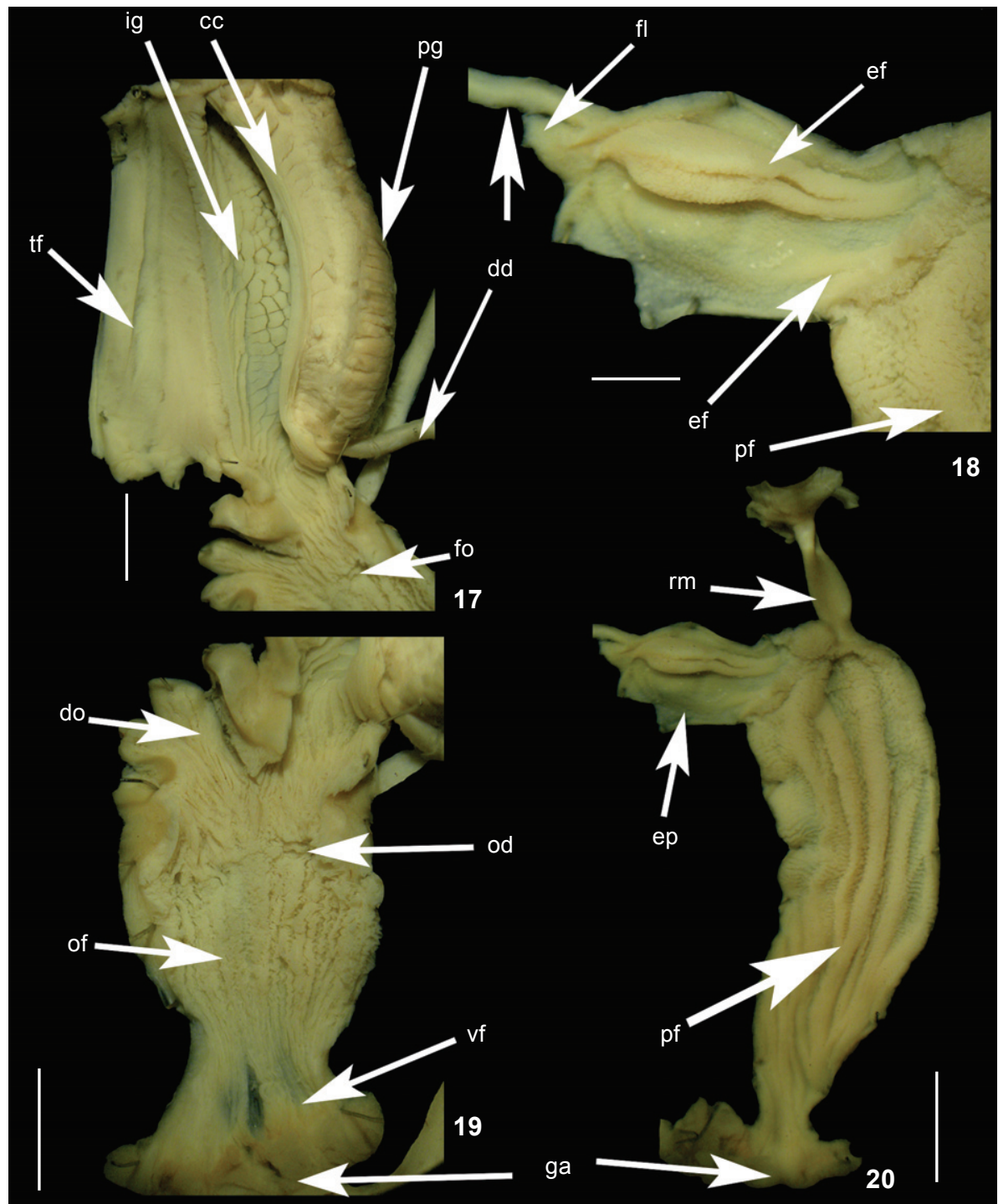

Figures 17-20. Internal surface of M. capillaceus genitalia: (17) spermoviduct; (18) epiphalus; (19) free oviduct and vagina. (20) epiphalus and penis. Scale bars: $17,19,20=5 \mathrm{~mm}, 18=2 \mathrm{~mm}$.

Megalobulimus capillaceus has often been confused with $M$. oblongus (Müller, 1774) and M. musculus, both from Argentina, and with M. separabilis. It is also similar to M. intertextus (Pilsbry, 1895), known from Brazil and Bolivia, and which can be found in dry habitats, contrasting with the humid habitats of $M$. capillaceus. Furthermore, M. capillaceus differs from $M$. intertextus, M. oblongus, and M. musculus in the shape of the shell. In the latter three species, the shell is more conical and has slender spires when compared with the shell of $M$. capillaceus. Bequaert (1948) reported this species from Peru, Bolivia, Brazil and Paraguay. The proportions of the specimen described from Paraguay and which is deposited at the FLMNH (UF 166264) are similar to the proportions of the typical $M$. capillaceus from Moyobamba, but the external shell features of that specimen are more similar to M. musculus. We therefore assign that specimen to M. musculus. The same holds true for the material from the FMNH (\#25925) and FLMNH (UF 022143) from Brazil. The material from the FLMNH (UF 022143) has been described from "Marigua" (sic FLMNH; Maringá), a locality in the state of Paraná, Brazil, which is next to Paraguay. The material previously attributed to $M$. capillaceus reported from Bolivia and deposited at the FLMNH and FMNH, is actually similar to $M$. intertextus and $M$. florezi sp. nov., and is herein assigned to $M$. intertextus. The morphological differences between $M$. capillaceus and M. separabilis are provided below, under M. separabilis. From the above, we conclude that M. capillaceus 


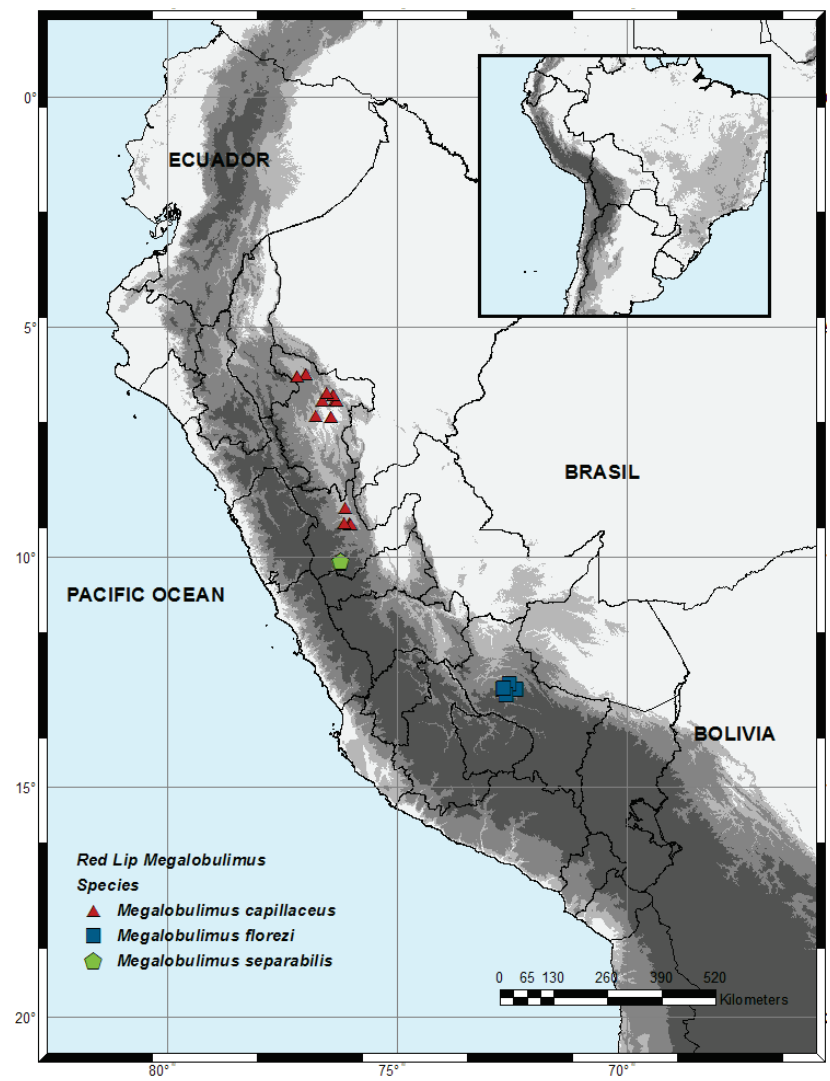

Figure 21. Distribution Map of red lip Megalobulimus from Peru.

is endemic to Peru and it is restricted to the San Martín and Huánuco regions, reaching the border of the Loreto region. The shape of the penis (cylindrical), the vagina longer than the free oviduct, and the spire measuring $1 / 7$ of the height of the shell are the main differences between M. capillaceus and the other red-lipped Megalobulimus from Peru. In genitalic features, M. capillaceus is more similar to M. oblongus, M. riopretensis Simone \& Leme, 1998, M. mogianensis Simone \& Leme, 1998, M. parafragilior Leme \& Indrusiak, 1990 and M. abbreviatus (Bequaert, 1948), but differs from them in the shape of the diverticulum of the free oviduct (bulb-like) and in the presence of two flagella (except for M. abbreviatus).

Material examined. Peru, San Martin: San Martín (Juan Guerra, 6³5'3.7"S, 76²19'20.7"W, 237 m), 5 spec., 28.i.2008, R. Ramirez \& C. Calderón leg. (MUSM-5585); (Morales, 6²8’24.6"S 76²3'31.1"W, 263 m), 5 spec., 29.i.2008, R. Ramirez \& C. Calderón leg. (MUSM-5586); (Partido alto, 6²8'18"S 76²2'14.6"W, 369 m), 9 spec., 6.ii.2008, C. Calderón leg. (MUSM-5587). Picota (Caspizapa, 657'15"S 76²5'7.8"W, 240 m), 3 spec., 05.ii.2008, R. Ramírez \& C. Calderón leg. (MUSM-5588). Moyobamba (Moyobamba, $6^{\circ} 02^{\prime} 11.2^{\prime \prime} \mathrm{S} 76^{\circ} 58^{\prime} 26.2^{\prime \prime W}, 887$ m), 8 spec., 31.i.2008, R. Ramírez \& C. Calderón leg. (MUSM-5589). Lamas (Lamas, 6²5’38.16"S 76³1'09.02"W, 743 m), 5 spec., 07.ii.2008, C. Calderon leg.
(MUSM-5590). Huallaga (Saposoa, 656'21.8"S 76²46'18.8"W, 318 m), 5 spec., 06.ii.2008, R. Ramírez \& C. Calderón leg. (MUSM5591); (Piscoyacu) 13 spec., 09.ii.2008, R. Ramírez \& C. Calderón leg. (MUSM-5592). Huánuco: Leoncio Prado (Tingo Maria, $\left.9^{\circ} 16^{\prime} 39.6^{\prime \prime} \mathrm{S} 76^{\circ} 00^{\prime} 41.9^{\prime \prime} \mathrm{W}, 747 \mathrm{~m}\right), 9$ spec., 6.vii.2009, V. Borda and C. Congrains leg. (MUSM-5593); (Picuroyacu, 9 ${ }^{\circ} 17^{\prime} 01.9^{\prime \prime S}$ $\left.76^{\circ} 01^{\prime} 0.2^{\prime \prime} \mathrm{W}, 657 \mathrm{~m}\right), 1$ spec., 6.vii.2009, V. Borda \& C. Congrains leg. (MUSM-5594); and (Aucayacu, 8 ${ }^{\circ} 55^{\prime} 31.5^{\prime \prime S} 76^{\circ} 06^{\prime} 44^{\prime \prime} \mathrm{W}, 571$ m), 4 spec., 7.vii.2009, V. Borda \& C. Congrains leg. (MUSM-5595).

\section{Megalobulimus florezi sp. nov. Figs 5-7, 25-33}

Borus capillaceus: Dall, 1912: 2 (non Pfeiffer, 1855) Strophocheilus (Megalobulimus) capillaceus: Bequaert, 1948: 120 (non Pfeiffer, 1855)

Strophocheilus (Megalobulimus) capitallaceus: (sic Flórez) Flórez, 1970: 29 (non Pfeiffer, 1855)

Diagnosis. Shell medium-sized, conic, with riblets; clubshaped penis, internal penial folds divided at the proximal third. Free oviduct longer than vagina. Kidney with triangular shape and is $2 / 3$ rds of pulmonary septum length.

Description. Living animals: Head and foot with brown color. With pair of bucal palps with lobulated border. Gonopore posterior to right omatophore.

Shell (Figs 5-7, Table I): Conic and small (up to $70 \mathrm{~mm}$ tall): Wider region in middle shell height. First and second whorls flattened. Third and fourth with thinner riblets, from suture to suture. Between riblets, small granulations with spiral disposition, appearing from the 2.6 whorls and reaching corporal whorl. Spire about $1 / 5$ shell height. Sutures deep. Periostracum between orange and brown. Umbilicus totally covered by outer lip. Digestive system (Figs 27 and 28): Buccal mass elliptic, highly muscular with posterior region slightly laterally expanded, radular pouch ventral. Retractor muscle inserted ventrally to buccal mass, anteriorly to radular pouch. Esophagus with three segments of same size: anterior, middle and posterior. Anterior segment with taller ridges and attached salivary glands. Ducts of salivary glands inserting dorso-posterior to buccal mass. Middle segment (crop) expanded, with thicker ridges, except in middle zone, smooth. Posterior segment with many thinner ridges and expansion seeming slightly cropped. Posterior segment receiving duct of anterior digestive gland. Esophagic typhlosole arising from duct of anterior digestive gland, reaching middle of stomach, increasing in thickness, with blunt end. Thin ridge arising from same duct, running beside esophagic typhlosole. Both end up in gastric shield. Stomach reniform, muscular. Posterior digestive gland connected to stomach through duct that ends next to gastric shield. Near intestine, internal surface with wavy ridges. These ridges are thinner than those in M. capillaceus. Stomach with central surface smooth in which both esophagic and intestinal typhlosole converge. Thicker walls near esophagus and intestine. Intestine with three segments. First segment 


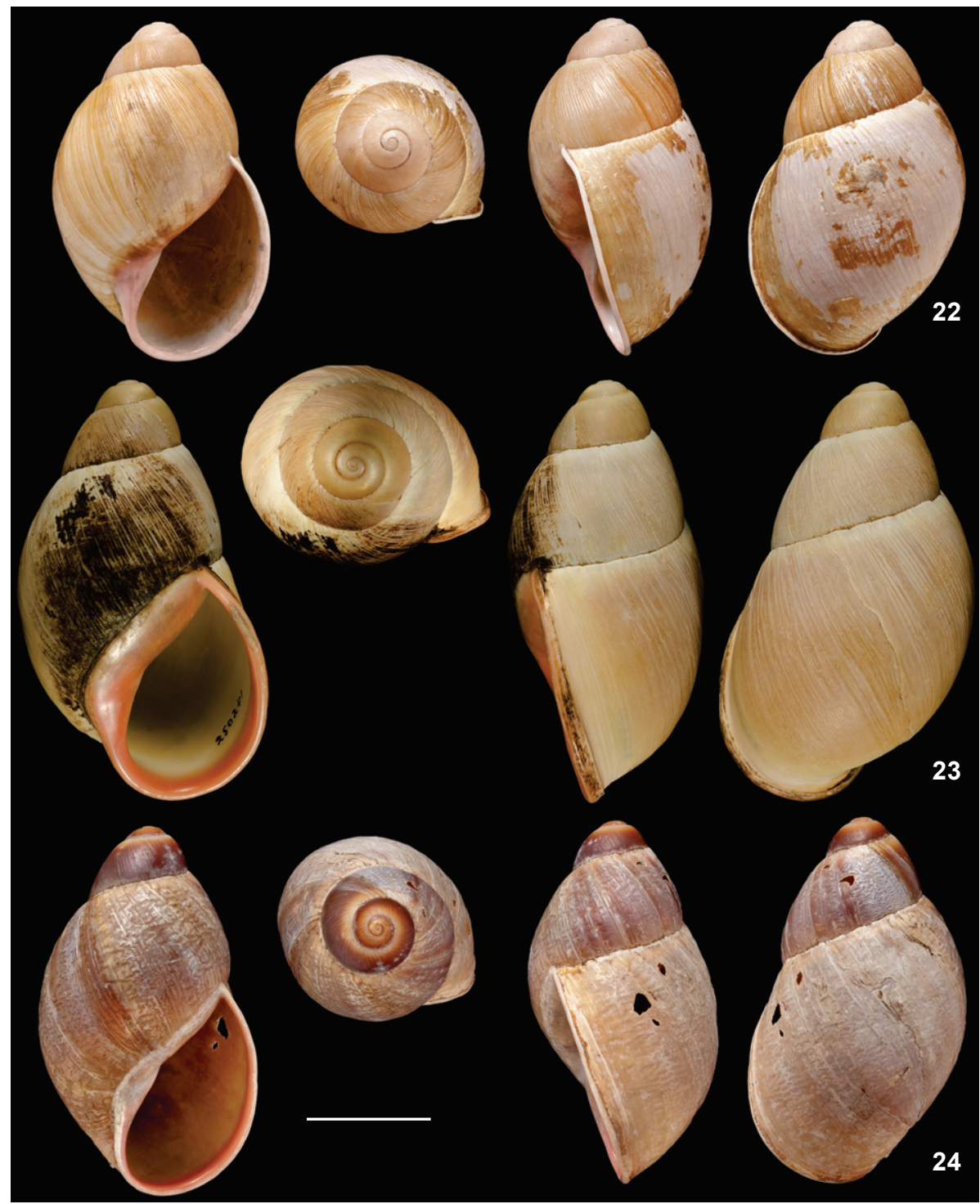

Figures 22-24. (22) Lectotype of M. capillaceus from NHMUK 1855 - 20130002, copyright NHMUK; (23) shells described by DALL (1912) like Borus capillaceus from USNM (250241), copyright USNM; (24) Syntype of Strophocheilus separabilis NHMUK 1903.11.20.39, copyright NHMUK. Scale bar: $20 \mathrm{~mm}$.

extending between stomach and pre-rectal valve. Externally, prerectal valve appears as two bulges with lobed edges. Intestinal typhlosole with folded surface, blunt end, arising from duct of posterior digestive gland, ending close to pre-rectal valve. Many ridges parallel to intestinal typhlosole, two thicker and near typhlosole, one ending close to terminus of typhlosole, other running to pre-rectal valve. Middle segment extending from prerectal valve, with oblique ridges that converge in a longitudinal ridge in V-disposition. Distal region (rectum) is the longest; with ridges in V-disposition, opening in the anus beside pneumostome in mantle collar. Pallial complex (Fig. 26): Septum continuous with anterior end of kidney, covered by network of vessels (rete mirabile-like) that expands to both sides of septum, partially covers kidney and pericardium (heart). Pulmonary network with two principal and longitudinal vessels. Vessel nearest to septum with major caliber, more ramified than other longitudinal vessels, $1 / 4$ th septum length. Second nearest originates at anterior end of cavity, ends on anterior end of kidney. Triangular kidney, 2/3rds septum length. Nephrostome on anterior third of right side of kidney. Posterior end of kidney does not reach the posterior end of ureteric groove, which is flanked by septum and rect. Heart covered by pericardium, sited anterior to kid- 


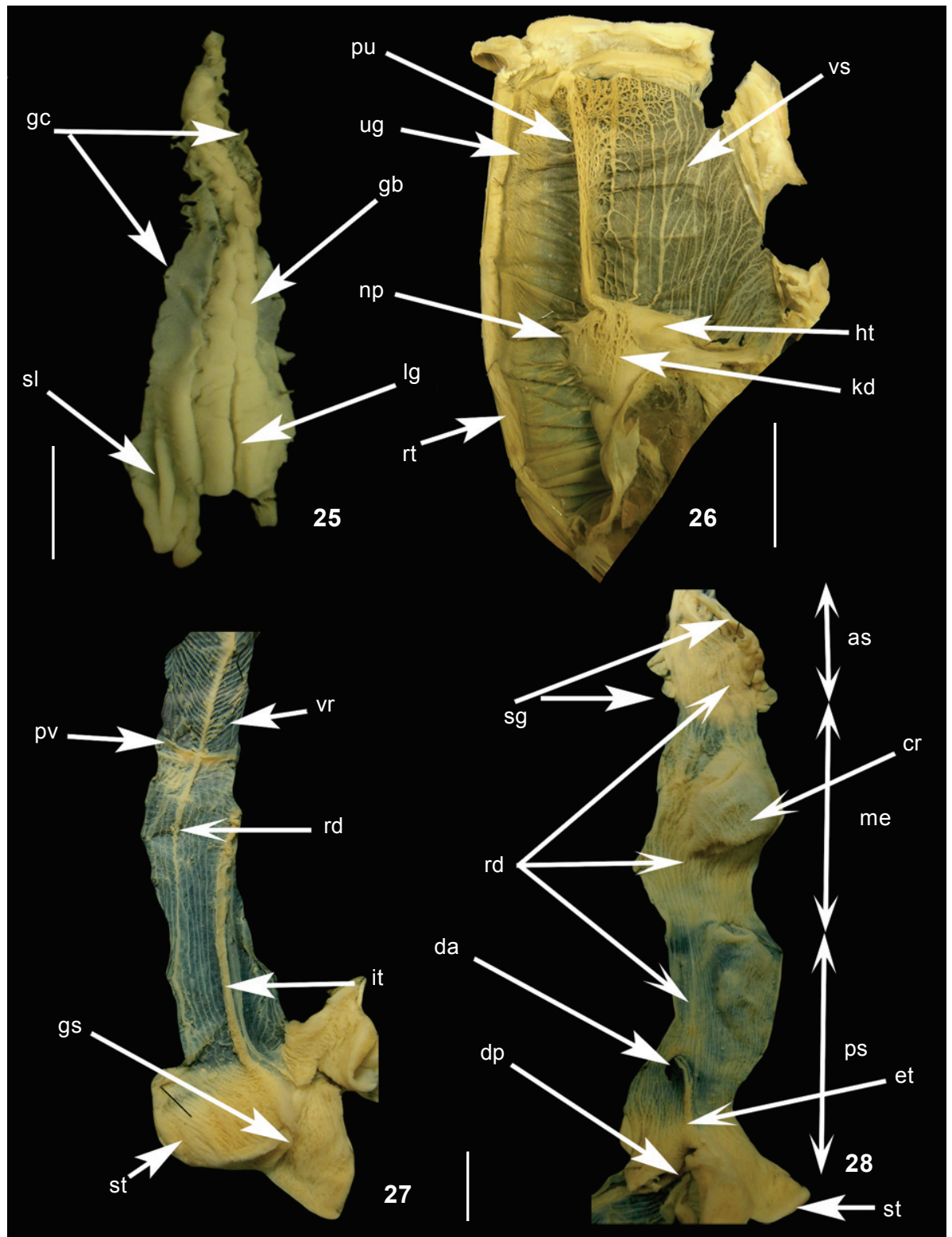

Figures 25-28. Soft parts of M. florezi sp. nov.: (25) internal view of the pedal gland; (26) pallial complex; (27) internal surface of intestine and stomach; (28) internal surface of esophagus. Scale bars: $5 \mathrm{~mm}$.

ney, half kidney length. Reproductive system (Figs 29-33): Gonad attached to posterior digestive gland, with three to five ducts that lead to hermaphroditic duct. Central portion of hermaphroditic duct dilated, stowed. Talon attached to annex glandular sac, receiving distal end of duct. Internally, with two chambers, of which one connects with hermaphroditic duct. Both chambers converge on a common duct through which albumin gland and annex glandular sac deposit their secretions. Annex glandular sac piriform, attached to concave region of albumin gland, inner surface rough with small concavities. Al- bumin gland reniform, variable in size, creamy color. Spermoviduct cylindrical, muscular, slightly curved. Prostatic gland extending over dorsal surface of spermoviduct, pink, with transversal folds. Ventral surface of spermoviduct slightly translucent. Internally, with two parallel regions; one with protrusions arranged like irregular plates that change their appearance to folds at the distal third; the other with small transversal folds. Both regions creamy in color. Internally, prostatic gland with many small ducts ending independently in collector channel that runs along gland, continues with deferens duct hidden at 


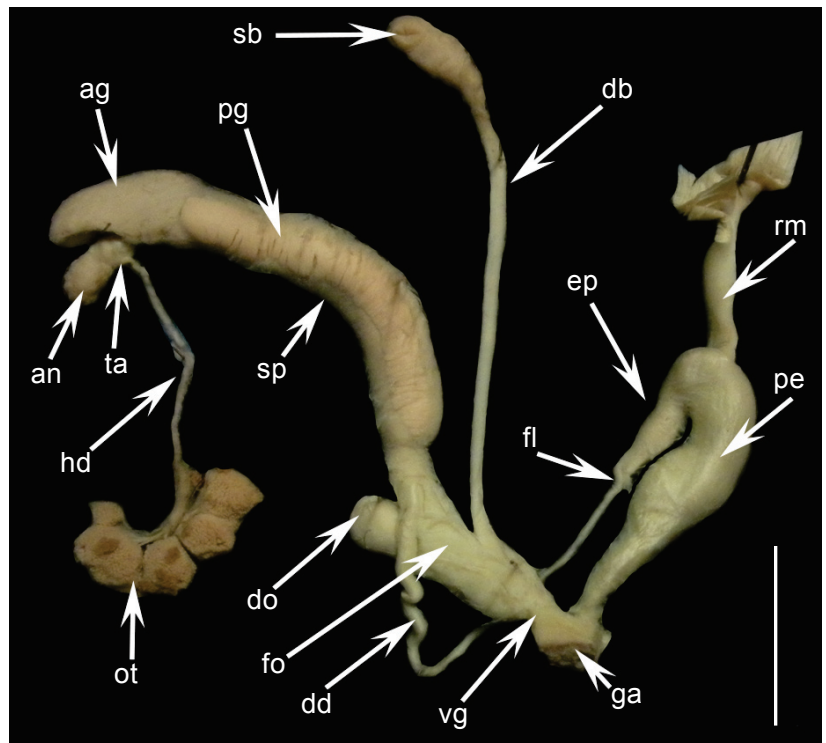

Figure 29. Genital system of M. florezi sp. nov. from Cusco region. Scale bar: $10 \mathrm{~mm}$.

beginning. Free oviduct with external bulb-like diverticulum located at mid-length, opposite to spermatolitic bursa duct. Inner surface of oviduct with many wide folds, some of which continue in diverticulum. Free oviduct longer than vagina. Vagina outer surface similar to that of free oviduct. Proximal region of its inner surface with thicker folds than those of free oviduct, reducing their thickness as they extent toward genital atrium. Spermatolitic bursa piriform, variable in size. Deferent duct ending suddenly in epiphallus, which lies over penis. Epiphallus with two short flagella, the same length or not. Epiphallus inner surface with small granulations; with thick fold (pilaster) on proximal region and then divided in two at the end of first fifth of epiphallus length. The two new folds with homogenous surfaces decrease in thickness as they approach distal end. These folds may converge to a single fold close to distal end or reach distal end independently. Another fold from middle of epiphallus to its end, wider but low, almost at the same level of epiphallus surface. Penis muscular, club-shaped, two times length of epiphallus. Retractor muscle half length of penis, with unique insertion to penis at variable position, which may be apical or subapical. Internally, penis distinguished by abrupt increase in fold number and rough surface. Some penial folds anastomosed to finish at proximal third; these folds have network aspect; also, on the distal half, penial folds increasing in thickness but then decreasing to low relief. Genital atrium almost indistinguishable. Pedal gland (Fig. 25): Depressed, triangular form, undulated borders, length $(23.45 \mathrm{~mm})$ spans visceral cavity in contracted specimen. Anterior third constant in width, covered by thin connective tissue, and then free. Posterior third thin, blunt, attached to foot by few connective bundles from lateral borders of gland. Gland capsule semi-transparent.
Lumen reduced, spans entire gland length. Glandular body with cream color, smooth surface, prominent, obliterating the lumen; it dangles on the capsule roof by projections attached to laterodorsal surface. Medium longitudinal groove spanning the entire length. Groove depth shallower in posterior region. Inside glandular body, glandular acinous separated from each other by capsule roof projections. Capsule floor smooth, presenting a small lifting along middle line of anterior portion, coinciding with gland body groove.

Measurements of holotype: height $66.62 \mathrm{~mm}$, width $41.42 \mathrm{~mm}$, aperture height $35.18 \mathrm{~mm}$, aperture width 19.32 $\mathrm{mm}$, spire height $15.52 \mathrm{~mm}$, position of major diameter 35.72 $\mathrm{mm}$, lateral width $35.00 \mathrm{~mm}, 5.7$ whorls.

Material examined. Holotype, Peru, Cusco: La Convención province, (Quillabamba, 1252'42.2"S 7241'41.4"W, $1094 \mathrm{~m}$ ), 27-III-2009, V. Borda leg. (MUSM 5005). Paratypes - Peru: Cusco: La Convención (Santa María, 1300'16.2"S 72³7'57.1"W, 1215 m), 1 spec., 20.iii.2012, V. Borda leg. (MUSM-5600/1); (Quillabamba, 1252'42.2"S 7241'41.4"W, $1094 \mathrm{~m}$ ) 3 spec., 27.iii.2009, V. Borda leg. (MUSM-5003/2) and FMNH 328305 (ex MUSM 5003/1); (Quillabamba, 1252'26.3"S 7242'07.3"W, 1138 m) 7 spec., 27.iii.2009, V. Borda leg. MUSM-5004/6 and SMF 336389 (ex MUSM 5004/1); (Quillabamba, 12 $52^{\prime} 42.2^{\prime \prime} \mathrm{S}$ $\left.72^{\circ} 41^{\prime} 41.4^{\prime \prime} \mathrm{W}, 1094 \mathrm{~m}\right), 3$ spec., 27.iii.2009, V. Borda leg. MUSM5005/2 and MZUSP 99562 (ex MUSM 5005/1); (Quillabamba, $\left.12^{\circ} 53^{\prime} 09.8^{\prime \prime S} 72^{\circ} 41^{\prime} 27.5^{\prime \prime} \mathrm{W}, 1179 \mathrm{~m}\right), 1$ spec., 29.iii.2009, V. Borda leg. MUSM-5006/1; (Quillabamba, 1253'16.4"S 7241’30.4"W, 1203 m), 2 spec., 29.iii.2009, V. Borda leg. MUSM-5007/2; (Echarate, $12^{\circ} 46^{\prime} 11.4^{\prime \prime S} 72^{\circ} 32^{\prime} 21.7^{\prime \prime} \mathrm{W}, 1073 \mathrm{~m}$ ), 2 spec., 28.iii.2009, V. Borda, leg. MUSM-5008/2; (Palma Real, 1247'S $\left.72^{\circ} 40^{\prime} \mathrm{W}\right), 1$ spec., 09.xi.1974, Á. Flores leg. MUSM-3054/1 and (Quellouno, 13²1' S 7159’W), 1 spec., 29.iv.1974, Á. Flores leg. MUSM-2992/1. Calca (Pailabamba, $13^{\circ} 05^{\prime}$ S $72^{\circ} 13^{\prime} W$ ), 1 spec., 19.ii.1970, Á. Flores, leg. MUSM-3019/1. Urubamba (Machu Picchu, $\left.13^{\circ} 07^{\prime} \mathrm{S} 72^{\circ} 34^{\prime} \mathrm{W}\right), 1$ spec., 1.x.1966, A. Flores leg. MUSM2920/1.

Distribution (Fig. 21). Restricted to northern Cusco, Peru. Was reported only in the humid rain forest of La Convención and Calca province. In La Convención it is found from Huayopata to Quellouno, near the Vilcanota River, which is part of the Urubamba basin. In Calca, it is found only in Lares Valley, near La Convención.

Habitat. Humid tropical forest but also in gardens and backyards.

Etymology. This species is dedicated to Dr. Ángel Flórez (UNSAAC, Cusco, Peru) for his contribution to Peruvian malacology.

Remarks. Since the first report by DALL (1912) for Quillabamba, red-lipped specimens from Cusco were also considered to be M. capillaceus. Dall considered this species to be like Borus capillaceus, and his eight shells were deposited in the Malacological collections of the USNM (250241) (Fig. 23). These shells have the same aspect of $M$. florezi sp. nov. However, there are 


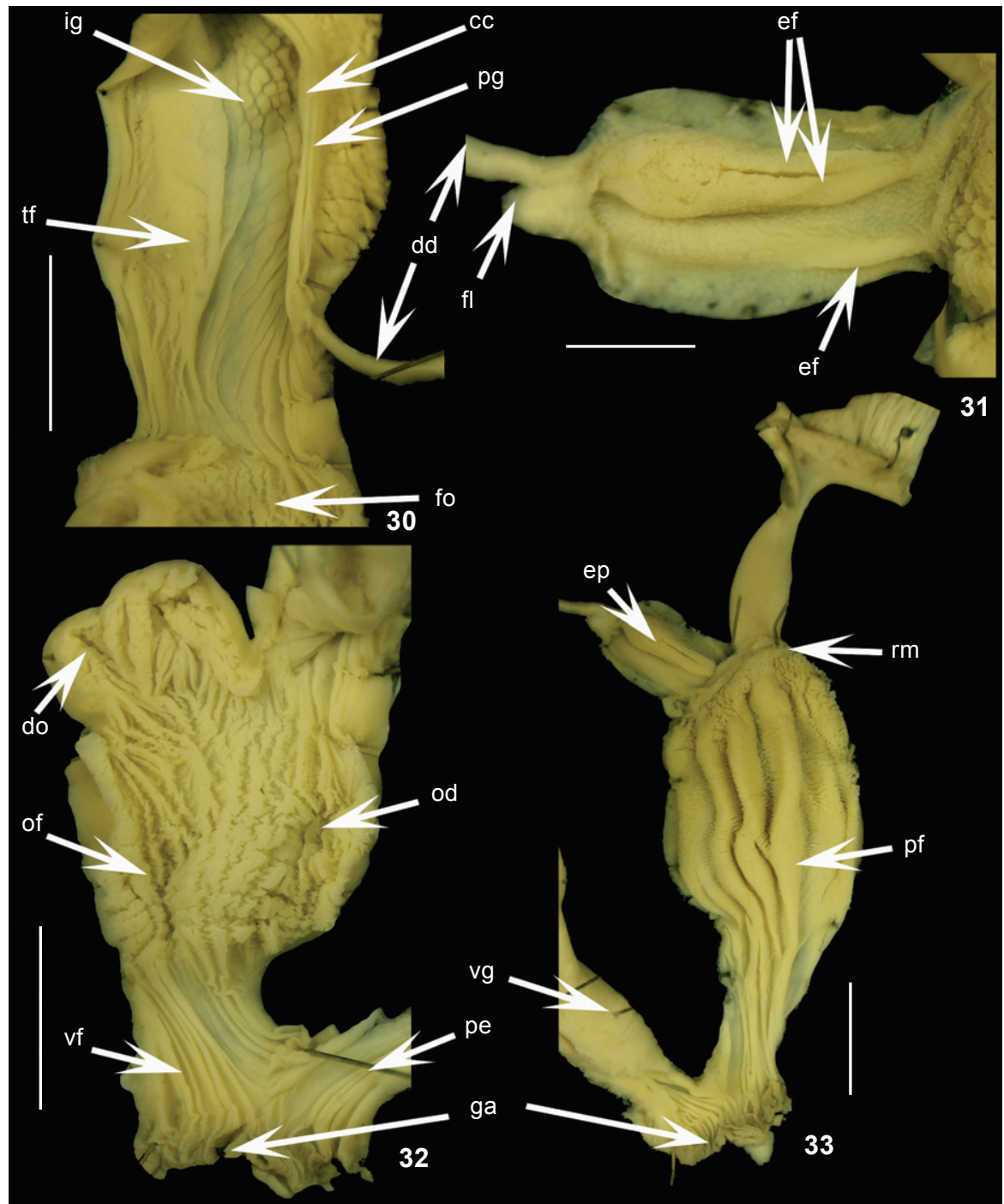

Figures 30-33. Internal surface of $M$. florezi sp. nov. genitalia: (30) Spermoviduct; (31) epiphalus; (32) free oviduct and vagina; (33) epiphalus and penis. Scale bars: $30-33=5 \mathrm{~mm}, 31=2 \mathrm{~mm}$.

several other characters that clearly discriminate this new species from $M$. capillaceus. The shell spire, shape of penis (clubshaped), disposition of penial folds (folds are divided at the proximal third), vagina larger than free oviduct and size of kidney ( $2 / 3$ rds pulmonary septum length) are the main features that differentiate this species from M. capillaceus. The specimens identified as M. capillaceus from Bolivia and deposited in FMNH (216380) and FLMNH (166263) have closer similarity to $M$. intertextus than to M. florezi sp. nov.; it is likely that these specimens of M. capillaceus were actually M. intertextus. The shell of $M$. florezi sp. nov. differs from that of $M$. intertextus by having an elliptical shell aperture and greater number of whorls, 5.53 (mean) in M. florezi sp. nov. (this study) and 5.2 in M. intertextus (BEqUaert 1948).

\section{Megalobulimus separabilis (Fulton, 1903)}

Figs 8-10, 34-43

Strophocheilus (Borus) separabilis Fulton, 1903: 100.

Strophocheilus jenksianus Pilsbry, 1940: 58.

Strophocheilus (Megalobulimus) separabilis: Bequaert, 1948: 123. Megalobulimus separabilis: Ramírez y Cáceres, 1991: 67-74; Ramírez et al. 2003: 52.

Type. Syntype (1 dry specimen) NHMUK 1903.11.20.39.

Type locality. "Doubtfully from Peru" (Fulton, 1903). Type locality of Strophocheilus jenksianus: Huánuco, Upper Huallaga Valley, Peru.

Diagnosis. Body mass with yellowish-orange coloration, shell small-sized, conic with gray and brown coloration; fili- 


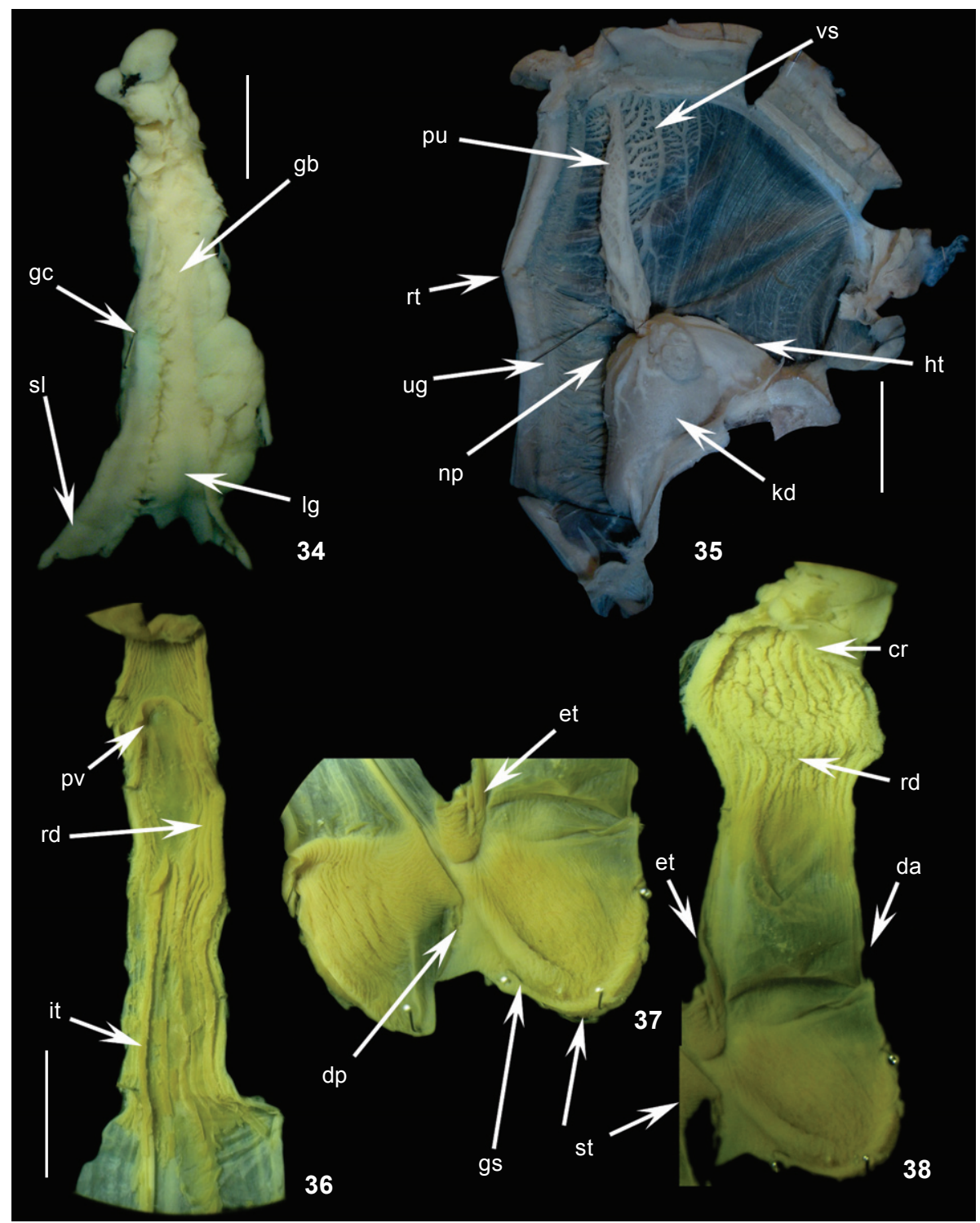

Figures 34-38. Soft parts of M.separabilis: (34) Internal view of the pedal gland; (35) pallial complex; (36) internal surface of intestine; (37) internal surface of stomach; (38) internal surface of esophagus. Scale bars: $34,36-38=5 \mathrm{~mm}, 35=10 \mathrm{~mm}$.

form male genitalia, bottle-shaped penis, epiphallus externally inconspicuous and free oviduct with internal diverticulum.

Description. Living animals: Foot with yellowish-orange coloration and head with orange coloration. Two buccal palps with lobulated borders. Gonopore posterior to the right omatophore. Shell (Figs 8-10, Table I): Conic, small (up to 70 $\mathrm{mm}$ ). Wider region below middle shell height. First and second whorls flattened. Third and fourth whorls with thinner riblets, from suture to suture. Between riblets, small granulations with spiral disposition, appearing from 2.8 whorls, reaching the corporal whorl. Spire about $1 / 5$ th shell height. Sutures deep.
Periostracum between gray and brown. Umbilicus totally covered by outer lip. Digestive system (Figs 36-38): Buccal mass elliptic, muscular, slightly laterally expanded on its posterior region. Radular pouch ventrally. Retractor muscle of buccal mass inserted anterior to radular pouch. Esophagus with three segments of similar size; anterior segment with taller ridges. Salivary glands attached to this segment. Ducts of salivary glands open in buccal mass. Middle segment (crop) expanded, with thicker ridges except in middle zone. Posterior segment with lateral bulge and many thinner ridges. This segment receives the duct of anterior digestive gland. Esophagic typhlosole and 
a ridge arising from this duct, reaching middle of stomach (gastric shield); at the same time, typhlosole increases its thickness and has blunt end. Stomach reniform, muscular. Posterior digestive gland connected to stomach through a duct that ends next to gastric shield. Internal surface near intestine with wavy ridges. Center of stomach with smooth surface where both the esophagic and intestinal typhlosole converge. Thicker stomach walls near esophagus and intestine. Intestine with three segments, three times esophagus length. First segment extends between stomach and pre-rectal valve. Externally, pre-rectal valve appears as two bulges with lobed edge. Internal surface of this segment with intestinal typhlosole with folded surface, with blunt end, arising from the duct of posterior digestive gland and ending close to pre-rectal valve. This typhlosole is thicker than in M. capillaceus and M. florezi sp. nov. Many ridges parallel intestinal typhlosole, two of which are thicker; one with the same size of typhlosole; other running to pre-rectal valve. Middle segment extends from pre-rectal valve, with oblique ridges that converge in a longitudinal ridge in $\mathrm{V}$-disposition. Rectum longest, has ridges with $\mathrm{V}$-disposition, opens in anus beside pneumostome in the mantle collar. Pallial complex (Fig. 35): Septum continuous to anterior end of kidney, covered by network of vessels (rete mirabile-like) that expands to both sides of septum and covers kidney and pericardium (heart). Major expansion of this network in pulmonary region. Pulmonary network with two principal and longitudinal vessels. Vessel nearest to septum with major caliber, more ramified than other, $1 / 4$ th septum length. Second nearest originates at second third of septum and extends to kidney. Triangular kidney, 2/3rd septum length. Nephrostome sited on anterior third of right side of kidney. Posterior end of kidney does not reach posterior end of ureteric groove which is flanked by septum and rectum. Heart covered by pericardium, sited anterior to kidney. Reproductive system (Figs 39-43): Gonad attached to posterior digestive gland, with three to five ducts that end on hermaphroditic duct. Central portion of hermaphroditic duct dilated, stowed. Talon spherical attached to annex glandular sac, receives distal end of duct. Comprised of two chambers, one of them with connection with hermaphroditic duct. Both chambers converge on a common duct through which albumin gland and annex glandular sac deposit their secretions. Annex glandular sac piriform, attached to albumin gland, inner surface rough with small concavities. Albumin gland reniform with variable size, creamy color. Spermoviduct cylindrical, slightly curved. Prostatic gland with transversal folds, pink coloration. Ventral surface of spermoviduct slightly translucent. Internally, with two parallel regions of creamy color, one with surface folded, other having smooth surface. Internally, prostatic gland with many small ducts which end independently on collector channel that continues with the deferens duct, which is hidden at its origin. Muscular free oviduct without external diverticulum. Oviduct inner surface with wide folds (10 to 14). Thicker folds in proximal half that reduce lumen; at this level, with internal diver-

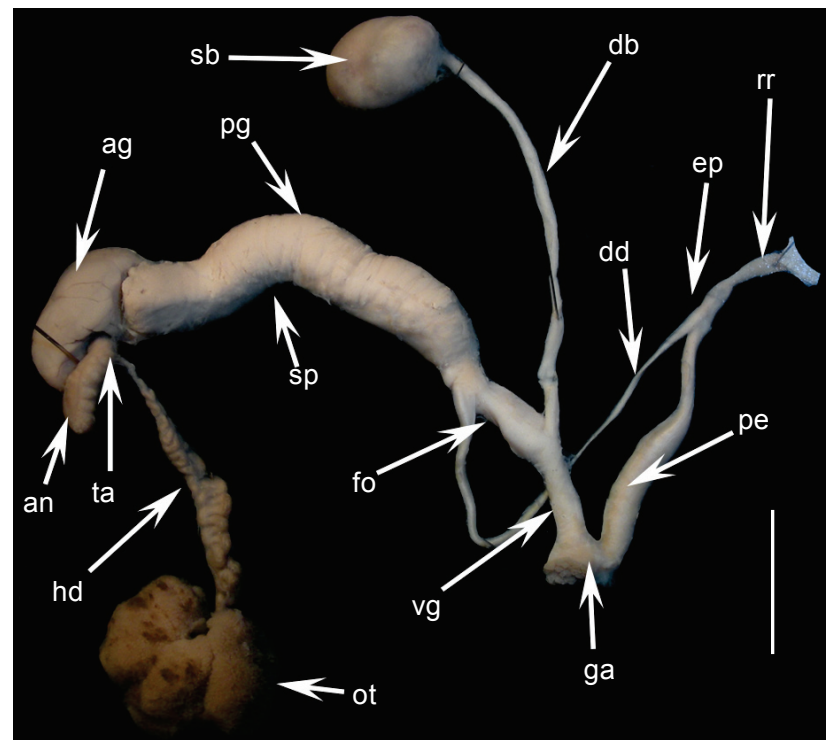

Figure 39. Genital system of $M$. separabilis from Huánuco region. Scale bar: $10 \mathrm{~mm}$.

ticulum, and folds continue inside it. Free oviduct longer than vagina. Outer surface of vagina similar to free oviduct. Proximal region of inner surface presents thinner folds than those of free oviduct, but these folds reduce their thickness as they arrive at genital atrium. Spermatolitic bursa piriform, variable in size. Externally, no clear demarcation between deferens duct and epiphallus; instead, there is slight expansion at end of deferens duct that continues to penis, folded over the latter. Internally, deferens duct with thin folds of oblique disposition; likewise, there are longitudinal folds that extend to the first half of the distal expansion (epiphallus). Epiphallus differentiated by presence of two longitudinal folds that increase their thickness at their middle and and run parallel up to the epiphallus-penis limit; surface with small granulations. Epiphallus almost $1 / 6$ th penis length. Epiphallus diameter constant, without flagellum. Penis bottle-shaped. Retractor muscle $1 / 3$ rd penis length, attached to penis only by a bundle of variable position, apical or subapical. Penis inner surface distinguished by abrupt increase of folds and rough surface. Penial folds divided, finishing at proximal third; these folds have network aspect, also their thickness decreases to a low relief. Genital atrium almost indistinguishable. Pedal gland (Fig. 34): Triangular form, undulated borders, depressed, length $(23.6 \mathrm{~mm})$ spans visceral cavity in the contracted specimen. Anterior third with constant width, covered by thin connective tissue, then free to its posterior end. Its posterior third thin, blunt, retained to foot by few connective bundles from its lateral borders. Gland capsule not transparent. Lumen reduced, its width almost half that of gland, spans entire length of gland. Glandular body with cream color, smooth surface, obliterates lumen, dangles on cap- 


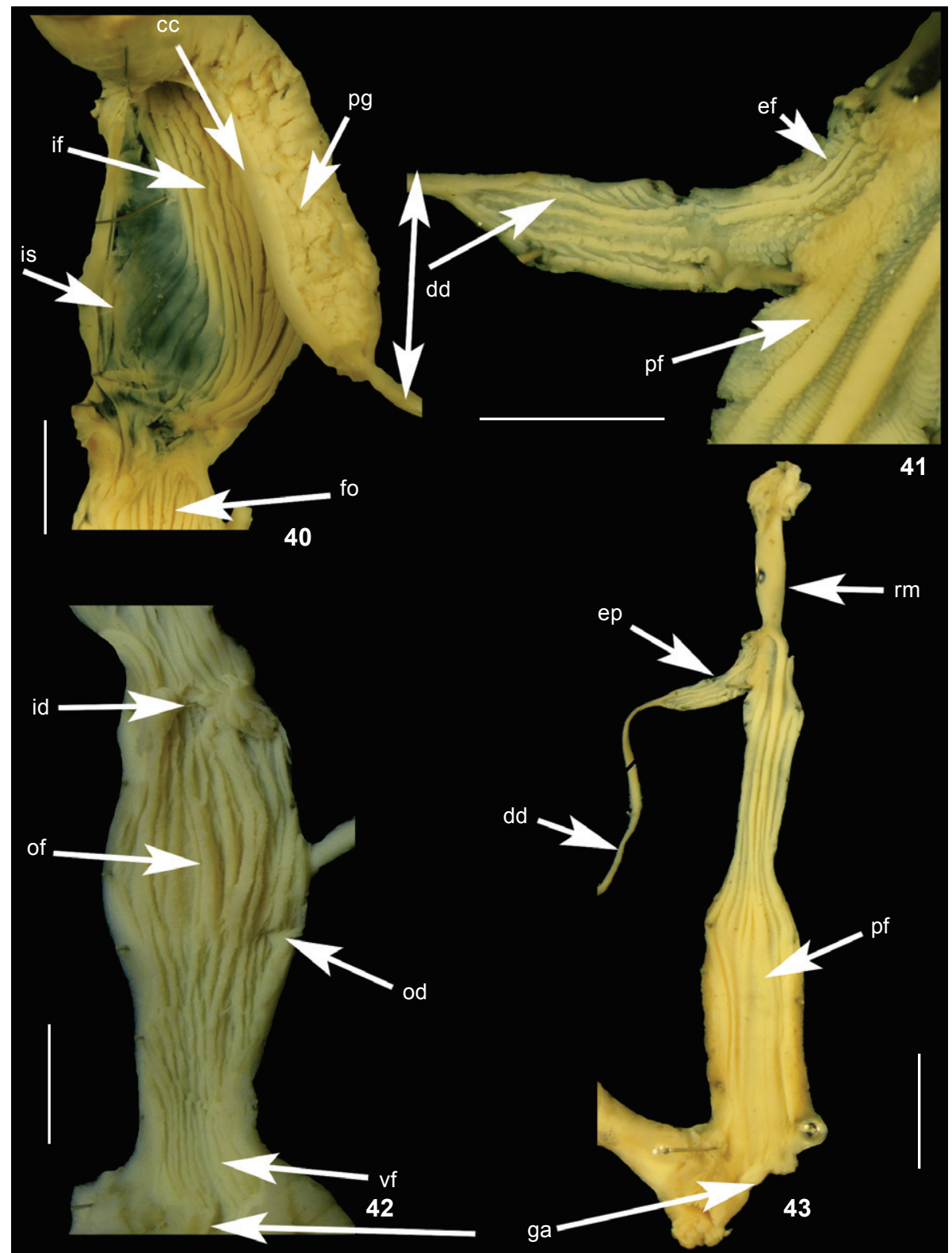

Figures 40-43. Internal surface of $M$. separabilis genitalia: (40) spermoviduct; (41) epiphalus; (42) free oviduct and vagina; (43) epiphalus and penis. Scale bars: $40,42-43=5 \mathrm{~mm}, 41=2 \mathrm{~mm}$.

sule roof by projections attached to latero-dorsal surface. On anterior third, glandular body with medium longitudinal groove that is shallower posteriorly Inside glandular body, acinous separated from each other by capsule roof projections. Capsule floor smooth, with small lifting along the middle line of anterior portion, coinciding with gland body groove.

Distribution (Fig. 21). This species is found only in the Ambo province in the upper Huallaga basin, in two localities, Ambo and Tomayquichua.
Habitat. Highlands of Ambo, which correspond to a dry steppe.

Material examined. Peru, Huánuco: Ambo (Ambo, $\left.10^{\circ} 07^{\prime} 38.4^{\prime \prime} \mathrm{S}, 76^{\circ} 12^{\prime} 30.6^{\prime \prime} \mathrm{W}, 2054 \mathrm{~m}\right), 1 \mathrm{spec}$. and 40 dry shells, 10.x.2009, V. Borda leg. (MUSM-5596); (Ambo, 1007'43"S, $\left.76^{\circ} 12^{\prime} 48^{\prime \prime} \mathrm{W}, 2053 \mathrm{~m}\right) 1$ spec. and 10 dry shells, 11.x.2009, V. Borda leg. (MUSM-5597) and (Tomayquichua, 1006'20"S, 76²'36"W, 2077 m), 1 spec., 12.x.2009, V. Borda leg. (MUSM 5598). 2 spec., x.1988, J. León leg. (MUSM-5599). 
Remarks. PILSBRY (1940) did not compare his Strophocheilus jenksianus with Strophocheilus (Borus) separabilis; BEQUAERT (1948) did not find differences between them, and we agree with him. The specimens examined by us have the same characteristics of the syntype of M. separabilis (NHMUK 1903.11.20.39) (Fig. 24). Megalobulimus separabilis is clearly different from the other redlipped Megalobulimus from Peru studied herein. Differences are in the shell (slender and gray coloration), epiphallus (not externally conspicuous) and free oviduct with an internal diverticulum. Megalobulimus separabilis is also considered endemic. The shell of $M$. separabilis is very different from those of other Megalobulimus, but some features of the genital system of this species are shared with other species of the genus. The shape of the penis of M. separabilis is similar to that of M. parafragilior, but M. parafragilior has a prominent epiphallus and an external diverticulum on the free oviduct (LemE \& InDRUSIAK 1990). The internal diverticulum is a character that has not been described before for any species of Megalobulimus. Likewise, the pedal gland of M. separabilis is different from the other red-lipped Megalobulimus described herein because the glandular body dangles on capsule on its lateral-dorsal surface; for this reason, the width of the lumen is reduced.

\section{Multivariate analysis}

The shells of the three red-lipped Megalobulimus species from Peru were differentiated by PCA using seven variables. The first component accounted for $60.67 \%$ of the variance and the variables that best explain this variation are lateral width (0.964) and shell width (0.918). The second component accounted for $29.53 \%$ of the variance with shell height (0.977) and position of major diameter $(0.737)$ best explaining this variation (Table II). The scatter plot of the two first principal components shows that M. separabilis occupies a different morphospace than the other species. This morphospace is wider than that of M. separabilis. Megalobulimus florezi sp. nov. has a morphospace very close to M. capillaceus but is better discriminated by its slender shell with a larger spire (Fig. 44). The populations of M. capillaceus from the two regions of Peru (Huánuco and San Martin) overlap. Individuals from Huánuco are inside the morphospace of the San Martín population and have great similarity with the largest individuals from San Martín.

Table II. Component Matrix for the variables evaluated in the ACP for the red lip Megalobulimus.

\begin{tabular}{lcc}
\hline \multirow{2}{*}{ Variable } & \multicolumn{2}{c}{ Component } \\
\cline { 2 - 3 } & 1 & 2 \\
\hline Shell height & 0.050 & 0.979 \\
shell width & 0.918 & 0.248 \\
Position of major diameter & -0.646 & 0.737 \\
Spire height & -0.825 & 0.505 \\
Aperture height & 0.854 & 0.367 \\
Aperture width & 0.804 & 0.335 \\
Lateral width & 0.964 & 0.034 \\
\hline
\end{tabular}

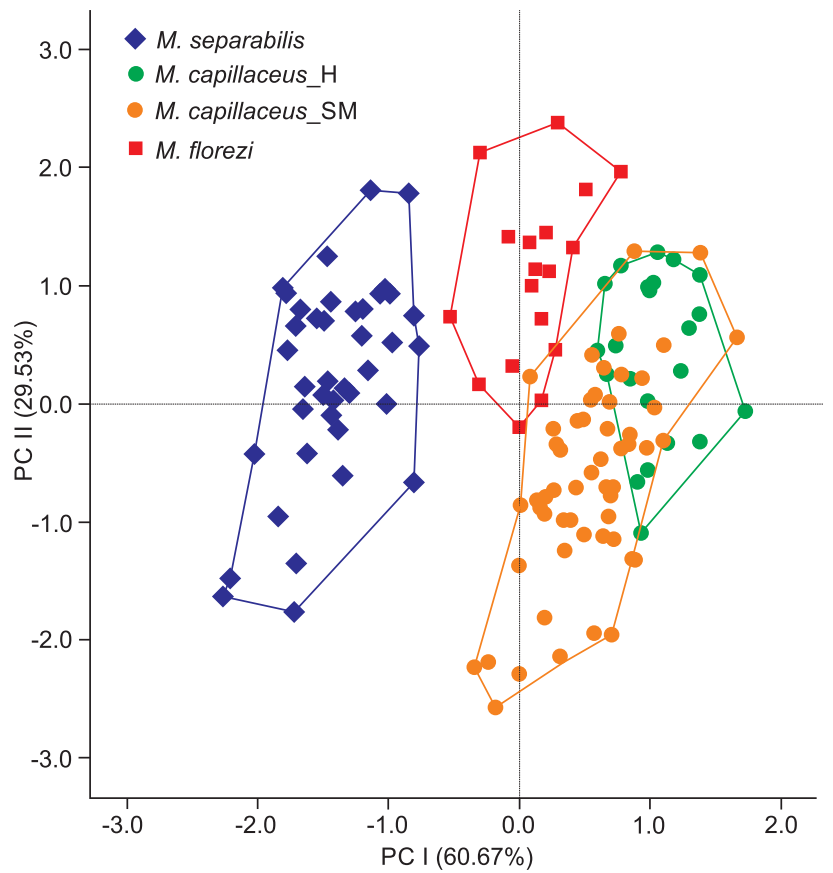

Figure 44. Discrimination of Peruvian red lip Megalobulimus from the principal component analysis (PCA) of 7 quantitative shell characters. The percentage of variation accounting for each principal component (PC) is given in parentheses. Two populations of $M$. capillaceus are distinguished by letters. $M$. capillaceus_H from Huánuco and M. capillaceus_SM from San Martín.

\section{DISCUSSION}

The main characters that provide information for differentiation among species are shell characters, the internal surface of the epiphallus, the internal folds of the penis, the free oviduct and the distribution of veins in the pulmonary cavity. Several authors have questioned the validity of shell information owing to the plasticity of conchological characters (KEMP \& Bertness 1984, Kool 1993, Emberton 1995). However, the PCA analysis allowed us to discriminate among the three species studied herein, based on shell characteristics.

Borda et al. (2010) described the pedal gland of several species of Megalobulimus, which can be clustered in two groups based on its capsule. Species of the first group, such as $M$. capillaceus, have a transparent capsule. We found that M. florezi sp. nov. belongs to this group because it displays a transparent capsule. This character is also shared with M. lorentzianus (HytronSсотт 1939). In the second group, the pedal gland has a thicker capsule. One example of a species in this group is M. lichtensteini; M. separabilis has this characteristic too. The diverticulum of the free oviduct described herein for both M. capillaceus and $M$. florezi sp. nov. was also described for other species of Megalobulimus, although by three different names; BAKER (1926) 
referred to it as the "short diverticulum" in M. oblongus, HyLtonScotт (1939), as the "bursa hastae" in M. lorentzianus, and SimONE \& LEME (1998) as the "free oviduct appendix" in M. riopretensis and M. mogianensis. Although this structure was described on each of these species, its function remains unknown (BAKER 1926, Hylton-Scott 1939, Leme 1973, Thomé et al. 1994). The presence of an internal diverticulum in the free oviduct of $M$. separabilis is considered a new character state, but it is not clear whether this state is ancestral or derived. The shape of the two folds of the epiphallus of both M. capillaceus and M. florezi sp. nov. is very similar to the state found in other species of Megalobulimus, as in $M$. oblongus, another red-lipped species; by contrast $M$. separabilis has very different folds, both in shape and disposition. In a molecular phylogeny of Megalobulimus from Peru (RAmírez et al. 2012), M. capillaceus formed a monophyletic group with M. oblongus, but not with M. separabilis, showing that shell lip color is a homoplastic character.

\section{ACKNOWLEDGMENTS}

Victor Borda and Rina Ramírez are researchers of the Museo de Historia Natural. Funding for this work was provided by grants from Rufford Small Grants Foundation to V. Borda and from Universidad Nacional Mayor de San Marcos (VRI-PEM2007B28, VRI-CSI091001041 and VRI-CSI101001091) to R. Ramírez. We thank C. Calderón, A. Ruiz and T. Robalino for their field assistance in San Martín, and C. Congrains in Huánuco. We thank D. Maldonado for helping with morphometric work, and J. Ablet (NHMUK), R. Hershler (USNM), J. Salpcinsky (FLMNH) and J. Gerber (FMNH) for providing images. We also thank S.Zimmitti, D. Robinson and O. Pell $\tilde{A}^{3} \mathrm{n}$ for help with translation.

\section{LITERATURE CITED}

BAKER, H.B. 1926. The Mollusca collected by the University of Michigan - Williamson Expedition in Venezuela Part IV. Occasional Papers of the Museum of Zoology University of Michigan 167: 1-49.

Bequaert, J.C. 1948. Monograph of the Strophocheilidae, a Neotropical family of terrestrial mollusks. Bulletin of the Museum of Comparative Zoology 100 (1): 1-210.

Bieler, R. 1992. Gastropod phylogeny and systematic. Annual Review of Ecology and Systematics 23: 311-338.

BonfatTi, I.D. 1980. Histologia do tubo digestivo de Megalobulimus (Gastropoda, Pulmonata, Stylommatophora, Megalobulimidae). Boletim do Instituto de Ciencias Biologicas e Geociencias, Juiz de Fora 28: 1-59.

Borda, V.; R. Ramírez \& P. Romero. 2010. Glándula pediosa de moluscos terrestres y sus implicancias evolutivas, con énfasis en Megalobulimus. Revista Peruana de Biología 17 (1): 43-52.

Burch, J. 1962. How to know the Eastern land snails. Dubuque, W.M.C. Brown Company Publishers, 214p.

Coppolino, M.L. 2010. Strategies for Collecting Land Snails and
Their Impact on Conservation Planning*. American Malacological Bulletin 28 (1-2): 97-103.

DALL, W.H. 1912. Report on landshells collected in Peru in 1911 by the Yale Expedition under Professor Hiram Bingham: with descriptions of a new subgenus, a new species, and new varieties. Smithsonian Institution Miscellaneous Collection 59 (14): 1-12.

Dimitriadis, V.K. 2001. Structure and Function of the Digestive System in Stylommatophora, p. 237-257. In: G.M. BARKeR (Ed.). The Biology of Terrestrial Mollusks. New York, CABI Publishing, 558p.

EMBERTon, K.C. 1995. When shells do not tell: 145 million years of evolution in North America's polygyrid land snails, with a revision and conservation priorities. Malacologia 3769 110.

Engel, F. 1970. Las lomas de Iguanil y el Complejo de Haldas. Lima, Departamento de Publicaciones, Universidad Nacional Agraria, 58p.

Flórez, A. 1970. Moluscos de interés económico del Oriente Cusqueño (Familia Acavidae). Publicaciones del Departamento Académico de Zoología y Entomología, Universidad Nacional de San Antonio Abad del Cusco, 1: 27-31.

Fulton, H.C. 1903. Figures and descriptions of supposed new species and varieties of Enea, Macrochlamys, Cochlostyla, Strophocheilus (Borus), Odontostomus (Moricandia), Leptopoma, Cataulus, Coptocheilus, and Trophidophora. Journal of Malacology 10: 99-103.

Gómez, B.J. 2001. Structure and Functioning of the Reproductive System, p. 307-330. In: G.M. BARKER (Ed.). The biology of terrestrial mollusks. New York, CABI Publishing, 558p.

Hylton-Scott, M.L. 1939. Estudio anatómico de Borus "Strophocheilus lorentzianus" (Doer). Revista del Museo de la Plata 7 (1): 217-278.

KEMP, P. \& M.D. BERTNESS. 1984. Snail shape and growth rates: Evidence for plastic shell allometry in Littorina littorea. Proceedings of the National Academy of Sciences 81: 811-813.

Kool, S.P. 1993. Phylogenetic analysis of the Rapaninae (Neogastropoda: Muricidae). Malacologia 35: 155-259.

Leme, J.L.M. 1964. Duas novas espécies de Strophocheilus do Brasil (Mollusca, Gastropoda). Papéis Avulsos do Departamento de Zoologia 16 (10): 97-110.

LEME, J.L.M. 1973. Anatomy and systematics of the Neotropical Strophocheiloidea (Gastropoda, Pulmonata) with the description of a new family. Arquivos de Zoologia 23 (5): 295-337.

LeME, J.L.M. \& L. IndRusiak. 1990. Megalobulimus parafragilior sp. nov., uma nova espécie de pulmonata terrestre de serra do mar (Gastropoda, Megalobulimidae). Papéis Avulsos de Zoología 37 (5): 97-105.

MarTens, E. 1876. Die Bulimus-Arten aus der Gruppe Borus. In: K. Pfeiffer (Ed). Novitates Conchologicae. Series Prima. Mollusca extramarina. Beschreibung und Abbildung neuer oder kritischer Land- und Süßwassermollusken 5: 1-26. 
Morelet, A. 1863. Séries conchyliologiques comprenant l'énumération de Mollusques terrestres et fluviátiles. III PEROU.

Nie, N.; C. Hull \& D. Bent. 2011. IBM statistical package for the social sciences. Chicago, Computer Software, SPSS v. 20.

Pfeiffer, L. 1855. Descriptions of Forty - seven - news species of Helicea, from collections of H. Cumings. Proceedings of Zoological Society of London: 91-101.

Pfeiffer, L. 1856. Versuch einer Anordnung der Heliceen nach natürlichen Gruppen. Malakozoologische Blätter 2: 145185

Pilsbry, H. 1895. American bulimi and bulimuli. Strophocheilus, Plekocheilus, Auris, Bulimulus. Manual of Conchology 2 (10): 1-213.

PILSBRY, H. 1940. Land Shell from Huánuco, Peru. Notulae Naturae, Academy of the Natural Science of Philadelphia, 56: 1-5.

Ramírez, R. \& S. Cáceres. 1991. Caracoles terrestres (Mollusca, Gastropoda) comestibles en el Perú. Boletín de Lima (77): 67-74.

Ramírez, R.; C. Paredes \& J. Arenas. 2003. Moluscos del Perú. Revista de Biología Tropical 51: 225-284.

Ramírez, R.; V. Borda; P. Romero; J. Ramirez; C. Congrains; J. Chirinos; P. Ramírez; L.E. Velásquez \& K. Mejía. 2012. Biodiversidad y endemismo de los caracoles terrestres Megalobulimus y Systrophia en la Amazonia occidental. Revista Peruana de Biología 19 (1): 059-074.
Ravines, R. 1991. Alimentos indígenas: Los Churos. Boletín de Lima 76: 25-28.

RuLL, V.2007. On the origin of present Neotropical biodiversity: a preliminary meta-analysis about speciation timing using molecular phylogenies. Orsis 22: 105-119.

SiMONE, L.R.L. 2006. Land and Freshwater Molluscs of Brazil. São Paulo, FAPESP/EGB, 390p.

Simone, L.R.L. 2012. Taxonomical study on a sample of pulmonates from Santa Maria da Vitória, Bahia, Brazil, with description of a new genus and four new species (Mollusca: Orthalicidae and Megalobulimidae). Papéis Avulsos de Zoologia 52 (36): 431-439.

Simone, L.R.L. \& J.L.M. Leme. 1998. Two new species of Megalobulimidae (Gastropoda, Strophocheiloidea) from north São Paulo, Brazil. Iheringia, Série Zoologia, 85: 189-203.

SмITH, E.A. 1894. Note on the variation and distribution of Bulimus oblongus Müller. Proceedings of the Malacological Society of London 1: 137.

Thomé, J.W.; A.N. Quillfeldt; M.T. Osorio; P.T. Campos \& V.I. SCHNeIDer. 1994. Manual de aulas prácticas de zoologia: estudo morfo-anatômico de um Molusco Gastrópode Mesuretra. Porto Alegre, Editora PUCRS, Série Zoologia, 32p.

Tundisi, J. \& T. Matsumura-Tundisi. 2008. Biodiversity in the neotropics: ecological, economic and social values. Brazilian Journal of Biology 68 (4): 913-915.

Submitted: 05.IV.2013; Accepted: 08.IX.2013.

Editorial responsibility: Marcos D.S. Tavares 